\title{
Analysis of International Law on Human Trafficking with Children as The Victims
}

\author{
Noer Indriati ${ }^{1 *}$ \\ ${ }^{1}$ Faculty of Law, Jenderal Soedirman University, Purwokerto, Indonesia
}

\begin{abstract}
Trafficking in person is interpreted as resulting from a State of social disorganization and crime caused by the variety of social-related things. The social change causes women and children to leave their homes and villages to seek a windfall to the region or another country with a reason to increase the standard of living. This research used normative juridical approach. The specification of research is descriptive, the analysis is juridical analytical, using secondary data that consist of primary and secondary and tertiary. The effective actions had to protect and eradicate the trafficking, especially the children. It needed international comprehensive approach from the countries of origin, transit and destination. The Government has an obligation to respect, to protect and to fulfill the rights of the child contained in some regulations. Trafficking of children as victims did not exactly use the way children are obtained, because the children did not know the purpose of the being sold.
\end{abstract}

\section{Introduction and literature review}

\begin{abstract}
Almost all countries in the world are experiencing problems on trading people, albeit with varying levels of difficulty. There is a country that became a place as the target of human trafficking, countries for the transit or countries as the source of the occurrence of trade people, without exception that plagued in Indonesia. [1] Human trafficking is a form of slavery, which occurs in the modern era with the aim of giving low living costs and can get a great benefit (big profits and cheap lives). [2] The case of human trafficking mainly women and children is a phenomenon of icebergs, where cases are not or have not yet come to the surface a lot more.
\end{abstract}

Human trafficking is the acts of recruitment, transportation, shelter, delivery, transfer or receipt of a person under threat of violence, use of violence, abduction, illegal confinement, forgery, fraud, abuse of power or vulnerable position, entrapment debt or give pay or benefits, so it is obtaining the consent of a person by having control over another person, both conducted in the country, for the purpose of exploitation or being exploited.

Children were the most easily and very vulnerable. This puts them at a very high risk, e.g. in relation to health, pressures and violence both in the form of physical or mental. The cause of a child becoming a victim is because some factors, such as: lifestyle (lifestyle

\footnotetext{
* Corresponding author: yuwantoindriati@gmail.com
} 
is undeniable currently triggering people to compete in unhealthy way); economic (poverty); Education (even though the country is said to be independent so many years already but there are still plenty of low-educated population, let alone that relation with poorness).

The efforts of the international community or the countries in preventing and eradicating transnational crime and international crime can be done with the cooperation of physically, or by pouring its settings in the Convention International. Today a lot of international treaties have been arranged with its enforcement area that is not at the level of international law, but rather at the level of national law due to come into contact directly with the legal interests of the citizens (individuals), for example: United Nations Convention Against Corruption 2003, United Nations Convention Against Transnational Organized Crime 2000. Such agreements are often referred to as standard/harmonizedsetting treaties. [3] This agreement does not create a norm, but only require the State to create norms within its national law.

\subsection{International Law of Treaties}

The sources of international law are normally associated with the provision of article 38 paragraph 1 of the Statute of the International Court of Justice. The article sets out the international law provisions that can be applied by the International Court of Justice in the exercise of its functions i.e., resolve the dispute submitted to it. It appears from the sentence that reads "the court, whose function is to decide in accordance with international law such disputes the U.S. are submitted to it, shall apply: .....", which is giving more information as follows:[4]

a. International convention, whether general or particular, establishing rules expressly recognized by the contesting states;

b. International custom, as evidence of a general practice accepted as law;

c. The general principles of law recognized by civilized nations;

d. Subject to the provisions of article 59, judicial decisions and the teachings of the most highly qualified publicist of the various nations, as subsidiary means for the determination of rules of law.

Understanding international treaties according to I Wayan Parthiana was: [5]

Agreeing between two or more subjects of international law regarding to an object or a specific problem with the intention to form of a legal relationship or give birth to the rights and obligations that are governed by international law.

Oppenheimer-Lauterpact argued that the Treaty was an agreement between Governments that creates rights and obligations between the Parties convene.

United Nations Convention Against Transnational Organized Crime 2000 is the Convention which governs transnational organized crime. The Convention is complemented with protocols that are targeted to a specific area and the manifestation of organized crime, namely: Protocol to prevent, suppress and punish trafficking in persons, especially women and children, supplementing the United Nations Convention Against Transnational Organized Crime; Protocol Against the Smuggling of Migrants by Land, Sea and Air; and Protocol Against the Illicit Manufacturing of and Trafficking in Firearms, their Parts and Components and Ammunition. The countries should become parties to the Convention before they can become parties to any of the protocols.

\subsection{Definition of Children}


The children referred to in the sense of children as the victims of criminal acts of trafficking of people in this research is a child with a certain age limit. Complementary trade protocol Convention on Transnational Organized Crime in the year 2000 mentioned the notion of a child is any person below the age of eighteen. The Convention on the rights of the child explains in part I article 1 that a child means every human being below the age of 18 years, unless under the law applicable to the child determined that the age of majority is attained earlier.

Determine the age of the strict to define the notions of children's influence on how children who are victims are treated by the law. Children cannot possibly permit himself to be exploited and/or give the ball over him. Likewise, in tribunal, they should be regarded as victims rather than as criminals. Connectedness with children as crime victims, cannot be defined only children who have actually been victimized due to the deeds of others.

\section{Objective of the study}

People trade in the sense of adults and children is two different things. Children are more susceptible to criminal acts that endanger either physical or mental. This is not only happens in national scope but also in the international community so that this research is necessary to analyze the international settings on child trafficking.

\section{Methodology}

This research is using descriptive research analytical legal specifications, with normative juridical approach method. Data source of the data used are secondary, which consists of a primary law, secondary materials and tertiary. Investigators' inventory on the positive laws, such as: the Convention-International Convention, protocols and international agreements by examining norms of law or legal principles.[6] Normative legal research was conducted towards the harmonization of the law or synchronization of legal materials have been obtained, and analyzed in Qualitative Juridical.

\section{Discussion}

Women and children are constituted the most vulnerable individuals and many become victims of criminal acts of human trafficking. The victims of trafficked are not only for the purpose of prostitution or other forms of sexual exploitation, but also includes other forms of exploitation, such as forced labor or services, slavery or practices similar to slavery even traded organs of their body. The crime trade is constantly evolving so as to inflict a lot of casualties from various walks of life, whether adult, children, men and women who generally are on the vulnerable conditions, and has no country is immune to acts of this criminal. In the international community, should be aware of, for example: Indonesia is the country of origin of the victims of criminal acts of trafficking people that ranked first in the world.[1]

The rights of child are an integral part of human rights, with the understanding that the children to be more expressing their feelings are human rights for children. The Convention on the rights of the children is a part that is not integral of the international instruments in the field of human rights. Children have special needs that relate to their situation as a weak figure/vulnerable, depending on the flower growing in the stage, therefore, there is a human right for the child. The Convention elaborated human rights that 
children everywhere have: the right to survival; the right to develop their fullest potential; the right to get protection from bad influences, abuse and exploitation, and to participate fully in family, community and social life.

The four principles of the Convention are non-discrimination; devotion to the best interests of the child; the right to life, survival and development; and respect for the views of the child. Each of the rights outlined in the Convention is inherent to the human dignity and harmonious development of every child. The Convention protects children's rights by setting standards in health care, education, and legal, civil and social services.[8]

Michael D. A. Freeman stated that the rights of the child to have the freedom of Association and freedom of Assembly, only subject to the restrictions that are necessary in a democratic society in the interest of national security, public safety, public order, protection of public health or morals or to protect the rights and freedoms of others.[9]

Article 1 Optional Protocol on the selling of children, prostitution and child pornography that States parties should prohibit the selling of children, child prostitution and pornography. Every country has the spirit of resistance against trafficking of child, a special group is vulnerable girls, face a higher risk against sexual exploitation, and they were not represented proportionally among those who sexually exploited. Article 2 (a) of this Protocol describes the notion of trafficking of child that means any act or transaction that is safe for a child, who was transferred to another person by another person or a group of people to acquire payment or other consideration. Article 3 gives the guarantee obligation that must be undertaken by participating countries. Paragraph 1 reads as follows: each participating countries/parties should ensure that as a minimum standard, deeds and the following activities are considered as acts of criminal or unlawful criminal, whether the crime was committed within the country or Interstate or based individuals or organizer.

International Labour Organization Convention No. 182 on the worst forms of work for children and International Labour Organization Convention No. 138 concerning the minimum age for work. Both the Convention supports the existence of a prohibition against trafficking of child. ILO Convention further explains that all forms of slavery or activities similar to slavery, such as trafficking of child, debt bondage, forced labor including recruitment of children in armed conflict is prohibited.

\section{Conclusion}

Some international law of treaties already set: United Nations Convention Against Transnational Organized Crime 2000 and Protocol to prevent, suppress and punish trafficking in persons, especially women and children, supplementing the United Nations Convention Against Transnational Organized Crime; Optional Protocol on the selling of children, prostitution and child pornography; International Labour Organization Convention No. 182 on the worst forms of work for children and International Labour Organization Convention No. 138 concerning the minimum age for work. Agreements such as this are often referred to as standard/harmonized-setting treaties. The Government has an obligation to respect, to protect and to fulfill the rights of the child contained in some regulations. The Convention are soft law, so there applies of submitted for every States. 


\section{References}

1. Sayuli Dewi Subagyo, Perbincangan ini kerjasama KBR68H dengan Kementerian Pemberdayaan Perempuan \& Perlindungan Anak, 24 Nopember 2011, $<$ http://www.kbr68h.com/perbincangan/diskusi-lepas/17471-perdagangan-orangkerjahatan-global-yang-mengerikan>, [20 Pebruari 2012].

2. K. Bales, Disposable People: New Slavery in the Global Economy, (University of California Press, Berkely, 1999). (Pendapat yang menyebutkan bahwa perdagangan orang dewasa ini identik dengan perbudakan dalam era modern. Lihat dalam John R. Wagley, Human Trafficking - An Overview, Washington, DC 20002: Center for Advanced Defense Studies, 2007).

3. D. D. Agusman, Hukum Perjanjian Internasional - Kajian Teori dan Praktik Indonesia, (Refika Aditama, Bandung, 2010)

4. F. S. Istanto, Hukum Internasional, (Universitas Atma Jaya, Yogyakarta, 1998)

5. I. W. Parthiana, Hukum Perjanjian Internasional - Bagian I, (CV Mandar Maju, Bandung, 2002)

6. B. Manan, Jurnal Hukum Puslitbangkum, 1, 4 (1999)

7. Ahmad Sofian, "Eksploitasi Seksual Komersial Anak:Buruknya Potret HAM Anak Di Indonesia", 6 Januari 2011,<http://hukum.kompasiana.com/2011/01/06/eska-buruknyapotret-ham-anak-di-indonesia-ahmad-sofian/>, [Jum'at, 23 Maret 2012]

8. M. D. A. Freeman, The Moral Status of Children: Essays on the Rights of the Child, (Martinus Nijhoff Publishers, Netherland, 1997) 